\title{
PHYSICIAN-ASSISTED SUICIDE IN AMERICA: REFLECTIONS ON ITS LEGALIZATION IN EUROPE
}

\author{
Laura GÓMEZ ABEJA \\ Departamento de Derecho Constitucional \\ Facultad de Derecho de la Universidad de Sevilla \\ lgomez2@us.es
}

\section{INTRODUCTION}

In many countries laws allow patients to put their life to an end when they face an incurable disease or when the sickness they suffer causes them an unbearable pain. This possibility usually takes shape through the withdrawal —or not commencement at all — of a life-sustaining treatment and it is called passive euthanasia. This action is, in any case, an exclusive call of the individual due to the fact that the decision to end one's own life belongs to the most personal and private sphere.

This paper assesses a different case in the context of ending one's own life, the legalization of the aid of a physician in committing suicide. The medical practitioner would prescribe —only prescribe - a lethal medication to the patient who demands it. Such a procedure is known as physician-assisted suicide.

The reason to analyse in particular the American system is due to the fact that several states in the U.S. have legalized physician-assisted suicide as a right. In Europe, on the contrary, what have been recognized as a right by some countries like Belgium, Netherlands or Luxemburg, is the (active) euthanasia. The doctor contribution is less direct in the case of physician-assisted suicide than in the case of euthanasia, and this fact makes the first procedure also less controversial than the second one. Therefore, physician aid in dying turns out to be a less problematic solution than euthanasia and it is also safer from a legal point of view both for the doctor and the patient. The recognition of this procedure to put the patient life to an end in some states of the USA could be taken into con- 
sideration with regards to its possible legalization over the next years in the European context.

The beginning of this matter in the U.S. lies in the mid 1990s, when some of the people and groups of the American society supporting the right to a physician-assisted suicide challenged a number of state laws that had punished suicide assistance. For this purpose, they aimed to extend the reasoning of the Supreme Court decision at Cruzan v. Director ${ }^{1}$. They argued that the liberty interest as stated in the Fourteenth Amendment encompassed the right to end one's own life, a supposed «right to die» ${ }^{2}$. Being so, since the right to die existed, it was also necessary to acknowledge the right to be helped by someone else to commit suicide. As a consequence of those appeals against legislations banning assisted suicide, the Supreme Court clarified its previous doctrine on the right to refuse medical treatment and its scope with regards to assisted suicide. These decisions would guide the state lawmakers on how to regulate this practice, a red-hot issue still today, recently included in several state legislations.

\section{THE UNITED STATES SUPREME COURT AND THE RIGHT TO REFUSE THE MEDICAL TREATMENT}

The United States Supreme Court ruled on the right to refuse medical treatment when it heard the case of young Nancy Cruzan, who was in a persistent vegetative state after being involved in a car accident. Once her parents knew for sure she would neither regain consciousness nor her condition would improve, they demanded the withdrawal of artificial nutrition and hydration that kept her alive. A judge's authorization was needed to achieve this purpose, and they got it from a trial court. At age twenty-five the patient had expressed that she would like to have her life-sustaining treatment removed if she ever were in her current situation, and the trial court found that it proved clearly enough her wishes, displaying her constitutional right to refuse the treatment.

${ }^{1}$ Cruzan v. Director, MDH, 497 U.S. 261, 270 (1990).

2 For more information, see A. Meisel and K. L. Cerminara, The Right to Die: The Law of End-of-life Decision-making, Englewood, Aspen Publishers, 2004, Chap. XII, p. 21; C. Tomás-Valiente Lanuza, La disponibilidad de la propia vida en el Derecho Penal, Madrid, Centro de Estudios Políticos y Constitucionales, 1999, pp. 217-267, and D. Gracia GuILléN, «Morir a tiempo. La eutanasia y sus alternativas», Claves de razón práctica, n. ${ }^{\circ} 152$ (2005), pp. 10-19. 
However, this decision was reversed by the Supreme Court of Missouri ${ }^{3}$, stating that the applicable state laws pursued the preservation of life, which overrides the «right to refuse». The Court found that the patient's statements before the accident did not prove her will sufficiently and, therefore, outweighed such public interest. Likewise, it rejected the reasoning accepting her parents to be entitled to make the decision on her behalf, concluding that no person can assume the choice for an incompetent in the absence of clear evidence of her wishes. The Court held that the role of an incompetent person's guardian stems from the state parens patriae $^{4}$ authority. Therefore, the guardian should act as the state would: always preserving life.

When the Supreme Court of the United States heard the case, it finally recognized the «right to refuse», a right that could already be found at an extensive case-law of state supreme courts and federal courts 5 .

Since the case involved an incompetent person, the Court would concern itself specially with this kind of patient. It is clear - the Supreme Court stated - that these people cannot make this decision in the exercise of the hypothetical right and therefore someone should do it on their behalf. Although the Missouri law recognized that a surrogate may make the decision, this should be done through a procedural safeguard to assure that the surrogate's action was the same as the patient's if she was competent. This safeguard required clear and convincing evidence of her desire to have life-sustaining treatments withdrawn. The question was then to determine if the United States Constitution forbade (to the law of Missouri) the establishment of this procedural safeguard. This clear and convincing evidence is the intermediate level of proof in the United States legal system and it means that there shouldn't be any substantial doubt (on the decision made) ${ }^{6}$.

${ }^{3}$ Cruzan v. Harmon, 760 S.W.2d 408 (Mo. 1988) (en banc).

${ }^{4}$ The concept parens patriae has its roots in the English Law, whereby a person makes a decision on behalf of another as if they had done it themselves if they were competent. However, in its adaptation to the U.S. Law, it loses its subjective element. The exercise of the parens patriae power means in this context making the decision on behalf of the incompetent looking for his or her best interest, understood as what the state and most of the people understood as appropriate. See P. SIMÓN LORDA and M. I. BARRIO, ¿Quién decidirá por mí?, Madrid, Triacastela, 2004, pp. 21-24.

5 Among others, the rulings in cases Erickson v. Dilgard, 44 Misc. 2d 27, 252 N.Y.S.2d 705 (Sup.Ct. 1962); In re Estate of Brooks, 32 Ill.2d 361 (1965); In re Osborne, 294 A.2d 372 (D.C. 1972); In re Quinlan, 70 N.J. 10, 355 A.2d 647 (1976); or finally, Superintentendent of Belchertown State School v. Saikewicz, 373 Mass. 728, 370 N.E.2d 417 (1977).

${ }^{6}$ In the U.S. Law, there are three primary standards of proof: 1) preponderance of evi- 
The United States Supreme Court also recognized the competent's right to refuse treatment, taking as a reference both the common and constitutional law. On the one hand, as the Court would remind, the recognition of the right to bodily integrity has been developed further through the doctrine of the informed consent prior to the treatment. To this end, it quoted the most important case-law ${ }^{7}$ and the famous words of Judge Cardozo in the case of Schloendorff:

«Every human being of adult years and sound mind has a right to determine what shall be done with his own body; and a surgeon who performs an operation without his patient's consent commits an assault for which he is liable in damages» ${ }^{8}$.

The Court holds that the logical consequence of the informed consent doctrine is that the patient also has the right not to consent, that is, the right to refuse the treatment. This way it acknowledges the right to refuse as embodied in the common- law doctrine of informed consent, in the first place?.

On the other hand, the Court then mentioned the other potential pillar of the right, which is the basis thereof in a number of rulings ${ }^{10}$. According to the Court, the principle that a competent person has the constitutional right to refuse a treatment might be inferred from their previous decisions. In other words, it is assumed that the United States Constitution guarantees a competent person's right to refuse a medical treatment. Unlike many

dence, which is the lowest standard of proof, required in most civil cases. It requires that there is a greater chance of success by making the decision than by not making it;2) clear and convincing evidence, which is the middle standard of proof. This is also used in civil cases, as long as civil rights are at stake, and in some criminal procedures. The clear and convincing standard requires that the evidence presented is with a higher probability to be true and so clear as not to leave substantial doubts; 3 ) evidence beyond reasonable doubt is the one required in criminal cases and requires almost absolute certainty.

7 Among others, the main decisions adopted in Union Pacific R. Co. v. Botsford, 141 U.S. 250, 251 (1891), and Schloendorff v. Society of New York Hospital, 211 N.Y. 125, 12930, 105 N.E. 92, 93 (1914); quoted in Cruzan v. Director, MDH, 497 U.S. 261, 269 (1990).

${ }^{8}$ Schloendorff v. Society of New York Hospital, 211 N.Y. 125, 129-130, 105 N.E. 92 (1914).

9 «The logical corollary of the doctrine of informed consent is that the patient generally possesses the right not to consent, that is, to refuse treatment» [Cruzan v. Director, $M D H$, 497 U.S. 261, 270 (1990)].

${ }_{10}$ See, for instance, the judgments in cases State v. Perricone, 37 N.J. 463, 181 A.2d 751 (1962); Raleigh Fitkin-Paul Morgan Memorial Hospital v. Anderson, 42 N.J. 421, 201 A.2d 537 (1964); or in Holmes v. Silver Cross Hospital, 340 F. Supp. 125 (ND.Ill. 1972). 
other courts, the Supreme Court did not include this right as part of the privacy and chose instead to identify patient's autonomy with a Fourteenth Amendment's liberty interest:

«Although many state courts have held that a right to refuse treatment is encompassed by a generalized constitutional right of privacy, we have never so held. We believe this issue is more properly analyzed in terms of a Fourteenth Amendment liberty interest» ${ }^{11}$.

The question then arises as to why the Supreme Court does not relate the right to refuse medical treatment with the right to privacy. From my point of view there are two main reasons. Firstly we have the controversial nature of the right of privacy. Although it had been considered a fundamental constitutional right, the U.S. Constitution contains no express right to privacy. As the U.S. Supreme Court held in Roe v. Wade:

«The Constitution does not explicitly mention any right of privacy. In a line of decisions, however, going back perhaps as far as Union Pacific $R$. Co. v. Botsford, 141 U.S. 250, 251 (1891), the Court has recognized that a right of personal privacy, or a guarantee of certain areas or zones of privacy, does exist under the Constitution» ${ }^{12}$.

Despite of this doctrine, there have always been juridical and academic voices to discredit such a right. It is remarkable, for instance, the dis-

${ }_{11}$ Cruzan v. Director, MDH, 497 U.S. 261, 287 (1990).

${ }_{12}$ Roe v. Wade, 410 U.S. 113 (1973). The Supreme Court then specifies [Roe v. Wade, 410 U.S. 113, 152-153 (1973)]:

In varying contexts, the Court or individual Justices have, indeed, found at least the roots of that right in the First Amendment, Stanley v. Georgia, 394 U.S. 557, 564 (1969); in the Fourth and Fifth Amendments, Terry v. Ohio, 392 U.S. 1, 8-9 (1968); Katz v. United States, 389 U.S. 347, 350 (1967); Boyd v. United States, 116 U.S. 616 (1886), see Olmstead v. United States, 277 U.S. 438, 478 (1928) (J. Brandeis, dissenting); in the penumbras of the Bill of Rights, Griswold v. Connecticut, 381 U.S., at 484-485; in the Ninth Amendment, ibid., at 486 (J. Goldberg, concurring); or in the concept of liberty guaranteed by the first section of the Fourteenth Amendment, see Meyer v. Nebraska, 262 U.S. 390, 399 (1923). These decisions make it clear that only personal rights that can be deemed «fundamental» or «implicit in the concept of ordered liberty», Palko v. Connecticut, 302 U.S. 319 , 325 (1937), are included in this guarantee of personal privacy. They also make it clear that the right has some extension to activities relating to marriage, Loving v. Virginia, 388 U.S. 1, 12 (1967); procreation, Skinner v. Oklahoma, 316 U.S. 535, $541-542$ (1942); contraception, Eisenstadt v. Baird, 405 U.S., at 453-454; ibid., at 460, 463-465 [410 U.S. 113, 153] (J. White, concurring in result); family relationships, Prince v. Massachusetts, 321 U.S. 158, 166 (1944), and child rearing and education, Pierce v. Society of Sisters, 268 U.S. 510, 535 (1925), and Meyer v. Nebraska. 
senting voice of Justice Black in the Griswold v. Connecticut case, where he denied the existence of a supposed right of privacy, which is not protected by any constitutional provision:

«The Court talks about a constitutional "right of privacy" as though there is some constitutional provision or provisions forbidding any law ever to be passed which might abridge the "privacy" of individuals. But there is not» ${ }^{13}$.

Specially after the assumption that the right to abortion fell within the right to privacy, a very intense legal debate and a lively controversy arose in the American society. It was in Roe v. Wade where the U.S. Supreme Court held that:

«This right of privacy, whether it be founded in the Fourteenth Amendment's concept of personal liberty and restrictions upon state action, as we feel it is, or, as the District Court determined, in the Ninth Amendment's reservation of rights to the people, is broad enough to encompass a woman's decision whether or not to terminate her pregnancy» ${ }^{14}$.

But then years later, in a new case related to the right to abortion, the Supreme Court reduced the level of constitutional acknowledgment of privacy. It was in Planned Parenthood v. Casey, in 1992, when the Court affirmed that:

«In Roe v. Wade, the Court recognized a "guarantee of personal privacy" which "is broad enough to encompass a woman's decision whether or not to terminate her pregnancy" [410 U.S., 113, 152-153 (1973)]. We are now of the view that, in terming this right fundamental, the Court in Roe read the earlier opinions upon which it based its decision much too broadly. Unlike marriage, procreation, and contraception, abortion "involves the purposeful termination of a potential life" [Harris v. McRae, 448 U.S. 297, 325 (1980)]. The abortion decision must therefore be recognized as sui generis, different in kind from the others that the Court has protected under the rubric of personal or family privacy and autonomy [...] Nor do the historical traditions of the American people support the view that the right to terminate one's pregnancy is "fundamental" ${ }^{15}$.

13 Griswold v. Connecticut, 381 U.S. 479, 508 (1965).

${ }^{14}$ Roe v. Wade, 410 U.S. 113, 153 (1973).

15 The following aspects of the judgment in case Planned Parenthood v. Casey [505 U.S. 
This first argument is closely linked with a second reason that I mentioned before. The identification of the right to refuse treatments with the privacy would mean - according to the opinion of several authors- ${ }^{16}$ recognizing it as a fundamental right, which would have different consequences as if it was a «mere» constitutional right. Basically, the laws restricting the fundamental rights must pass strict scrutiny ${ }^{17}$, which means that the legal regulation or decision must be justified by a compelling state interest, which needs to be protected. Furthermore, its only purpose must be serving that compelling interest and in order to protect it, it must use the least restrictive means. However, the «non-fundamental» constitutional rights may be regulated by rules to which a different level of scrutiny is applied. The so-called rational basis review is used to determine if the law or policy is reasonable to achieve a goal pursued by the state. It demands this law or policy to be rationally related to a legitimate state interest, which must neither be compelling nor the pursued interest: it is enough that the law or policy pursues a legitimate interest ${ }^{18}$.

833 (1992)], might be highlighted: the decision obviates any mention to the concept of privacy (except for the case citations and the dissenting votes). Likewise, it reduces the level of scrutiny, which determines the constitutionality of U.S. acts. Although the highest level of scrutiny had been established for the acts limiting the right to abortion — strict scrutiny - conceived for certain fundamental constitutional rights, Planned Parenthood v. Casey applied a less restrictive level of scrutiny — rational basis-, and eventually recognized viability as the point at which the state interest in the life of the fetus outweighs the right of the woman to abort, which means that abortion may be banned entirely from the moment the fetus is viable. Unlike what was established in Roe, a fetus can be considered viable after 22 or 23 weeks, and not at 28 weeks of gestation.

16 Among others, C. JuAnatey Dorado, «La disponibilidad del derecho a la vida en la jurisprudencia y en la legislación de los Estados Unidos de América», Jueces para la democracia, n. ${ }^{\circ} 45$ ( 2002), p. 61; J. Choper, R. Y. Fallon, Kamisar and S. Shiffrin, Leading Cases in American Constitutional Law, Saint Paul, Thomson West, 2007, p. 193, and C. TomÁsValiente LanuZa, La disponibilidad de la propia vida..., op. cit., pp. 219 et seq.

17 The levels of scrutiny were first applied in the case United States $v$. Carolene Products, in 1938, where three standards of judicial review for state laws were established (and by extension, of Governmental actions and courts decisions). The level of scrutiny applied to legislation involving fundamental rights or suspect classifications which can affect the Equal Protection Clause is the strict scrutiny. There is an intermediate level of scrutiny (intermediate scrutiny), also applicable when the Equal Protection Clause might be challenged. It must be proven that the law or policy furthers an important State interest in a way that is substantially related to that interest. Finally, the default standard of review that courts apply when considering constitutional questions is the rational basis review.

${ }^{18}$ In this decision the Supreme Court did not classify the public interests to which it referred. Nonetheless, it could be inferred that these are just legitimate interests (non-compelling), as the right to refuse medical treatment is conceived as a part of the Fourteenth Amendment's liberty interest. 
Therefore, and according to the most widely accepted doctrine, regulations restricting fundamental constitutional rights are presumably unconstitutional, whereas those restricting non-fundamental constitutional rights are deemed constitutional.

The difference between considering the right to refuse medical treatment as a fundamental or «just» a constitutional right is clear. And the idea that ruling it out as an expression of the privacy is a way to avoid such a strict control of the state laws regulating this right does not seem farfetched. The Supreme Court's intention seemed to be in fact leaving these questions to the discretion of the states, and the way to do it was to leave out the controversial right to privacy.

\section{THE SUPREME COURT AND THE RIGHT TO PHYSICIAN-ASSISTED SUICIDE}

\section{New York State Law banning Assisting Suicide}

The Supreme Court ruled on the constitutionality of the law banning the assisted suicide in the State of New York because of its potential violation of the Equal Protection Clause of the Fourteenth Amendment ${ }^{19}$. This is what the respondents stated in the case Vacco v. Quill et al. ${ }^{20}$, whom the Court of Appeals for the Second Circuit had ruled in favour of ${ }^{21}$. The Supreme Court's decision, which overruled the one by the Court of Appeals, can help us understand the extension of the previously acknowledged right.

The Equal Protection Clause, as the Court reminded, provides that «no state shall deny any person within its jurisdiction the equal protection of the laws», which implies a principle of equality rather than a substantive

19 The Equal Protection Clause is part of the Fourteenth Amendment and provides that «no state shall deny to any person within its jurisdiction the equal protection of the laws». The legislation involving suspect classifications, as well as those regulating fundamental rights, must pass strict scrutiny to assess its constitutionality, as a guarantee that the Equal Protection Clause has been applied.

${ }^{20}$ Vacco v. Quill et al., 521 U.S. 793 (1997).

${ }^{21}$ The respondents were some authorities on behalf of the state and three physicians who looked to prescribe lethal medication for mentally competent, terminally ill patients, who were suffering great pain and desired the doctors help in taking their own lives to an end. However, they were deterred from doing so by New York's ban on assisting suicide, which they considered violated the Equal Protection Clause since a competent person could refuse medical treatment, which in their opinion was essentially the same thing as physicianassisted suicide. 
right. Therefore, the states' duty is to treat similarly-situated individuals in a similar manner. However, different cases might be handled differently ${ }^{22}$. The Supreme Court finds that New York's laws on assisted suicide and the laws allowing patients to refuse medical treatments do not treat differently or make a distinction between citizens, as such laws establish that every competent person has the right to refuse medical treatments and that nobody is allowed to assist in another person's suicide.

If the Court of Appeals found that the different treatment had been unjustified, it was because its argument was based on a wrong premise: considering that a life-sustaining treatment and a physician-assisted suicide were essentially the same thing. The Supreme Court believes that there is an important difference between the two of them. In the first place, when a person refuses a life-sustaining treatment, he or she dies from the underlying condition. However, when a person who despite being terminally ill takes a lethal medication to end with his or her life, the cause of the death is that medication ${ }^{23}$. There is also a difference about intentionality: the doctor who withdraws a life sustaining treatment to the patient -who somehow asks for it - aims to respect that patient's wishes and to help stopping the suffering, and the same can be said when the doctor provides palliative medication. But this is not the aim in the case of assisted suicide, which looks for the death of the patient in the first place. The Supreme Court affirms that this variance of targets has been generally acknowledged by the courts and that it has also been reflected in several state laws, including New York act discussed in this decision.

The Supreme Court then clarifies its statements on the Cruzan case about an alleged right to die, stating now that although it recognized the protection of the right to refuse treatments as part of the liberty interest from the Fourteenth Amendment, the origin of this right is in the common law tradition and not in a supposed right to accelerate death, which would be a consequence of the refusal:

${ }^{22}$ Vacco v. Quill et al., 521 U.S. 793, 800 (1997); the Supreme Court quotes Plyler v. Doe, 457 U.S. 202, 216 (1982): «The Constitution does not require things which are different in fact or opinion to be treated in law as though they were the same». In this decision the Court cited also Tigner v. Texas, 310 U.S. 141, 147 (1940).

${ }^{23}$ The Supreme Court —Vacco v. Quill et al., 521 U.S. 793, 798 (1997)— quotes In re Conroy, 98 N.J. 321, 486 A. 2d 1209, 1226 (1985), one of the first where this statement was made, and also mentions a previous case, In re Colyer, 99 Wash. 2d 114, 123, 660 P. 2d 738, 743 (1983). Finally the Supreme Court cites People v. Kevorkian, 447 Mich. 436, 470-472, 527 N. W. 2d 714, 728 (1994), a case exposed to broad media coverage about a physician who had assisted in the death of many patients and who was later convicted. 
«In Cruzan v. Director [497 U.S. 261, 278 (1990)], we concluded that "[t]he principle that a competent person has a constitutionally protected liberty interest in refusing unwanted medical treatment may be inferred from our prior decisions", and we assumed the existence of such a right for purposes of that case. But our assumption of a right to refuse treatment was grounded not, as the Court of Appeals supposed, on the proposition that patients have a general and abstract "right to hasten death", but on well established, traditional rights to bodily integrity and freedom from unwanted touching [Cruzan, 497 U.S., 278-279, 287-288 (1990)]. In fact, we observed that "the majority of states in this country have laws imposing criminal penalties on one who assists another to commit suicide" $\gg^{24}$.

The Court held consequently that the assisted suicide legislation does not affect the constitutional rights - whether they are fundamental or not - and that it does not contain any «suspect classification ${ }^{25}$. Therefore, as already mentioned when examining the Cruzan case, there is a strong presumption of constitutionality in this statute. The Court finally stated that the law also responds to legitimate state interests, a necessary requisite so that certain interests or rights can be limited ${ }^{26}$.

\section{Washington State Law banning Assisting Suicide}

The constitutionality of the law forbidding assisted suicide was likewise questioned in the State of Washington. In the Washington et al. v. Glucksberg et al. ${ }^{27}$ case a group of four physicians, three terminally-ill patients - who had already died when the United States Supreme Court heard the case- and the non-profit organization «Compassion in dying», that supported patients seeking physician aid in dying, asked the U.S. District Court to declare this

${ }^{24}$ Vacco v. Quill, 521 U.S. 793, 807 (1997).

${ }^{25}$ Vacco v. Quill, 521 U.S. 793, 799 (1997):

The Equal Protection Clause commands that no state shall «deny to any person within its jurisdiction the equal protection of the laws. This provision creates no substantive rights» [San Antonio Independent School Dist.v. Rodriguez, 411 U.S. 1, 33 (1973)]. Instead, it embodies a general rule that states must treat like cases alike but may treat unlike cases accordingly [Plyler v. Doe, 457 U.S. 202, 216 (1982)]. «[T] he Constitution does not require things which are different in fact or opinion to be treated in law as though they were the same» [Tigner v. Texas, 310 U.S. 141, 147 (1940)].

${ }^{26}$ These state interests will be further analyzed in Washington v. Glucksberg, another Supreme Court case decided together with Vacco.

27 Washington et al. v. Glucksberg et al., 521 U.S. 702 (1997). 
law unconstitutional ${ }^{28}$. The plaintiffs held that this law limited the liberty interest from the Fourteenth Amendment, since this liberty entailed the right of an adult with a terminal illness to commit physician-assisted suicide. The District Court initially ruled in their favour. Then a panel of the Court of Appeals for the Ninth Circuit reversed, but the Ninth Circuit reheard the case en banc ${ }^{29}$, reversed the panel's decision, and affirmed the District Court decision, later appealed to the federal Supreme Court.

The Supreme Court reminds that when hearing due process cases ${ }^{30}$, it is necessary to start by analysing the historical background, legal traditions and praxis. After reviewing the state statutes, the Court concludes that the assisted suicide is in most cases punished. Likewise, in the common law tradition, both committing suicide and helping someone to die have been traditionally penalized. Although the stance on suicide has evolved over the years ${ }^{31}$, the opinion on assisted suicide has not. Indeed, the latter is still banned despite the new reflections upon the concept of death due to the new life-sustaining treatments arisen in modern medical technology.

Besides, the Supreme Court reminds that the Due Process Clause guarantees more than a fair process, and the liberty it protects implies more than the absence of physical restraint. However, it is cautious as to considering when a liberty is part of the constitutional liberty interest. In order to do so, the asserted liberty must have two primary features: firstly, it must

\footnotetext{
${ }^{28}$ «A person is guilty of promoting a suicide attempt when he knowingly causes or aids another person to attempt suicide» [Wash. Rev. Code 9A.36.060 (1) (1994)].

${ }^{29}$ Compassion in Dying v. Washington, 79 F. 3d 790, 798 (1996).

30 The Fifth and Fifteenth Amendments provide that no person shall be deprived of life, liberty, or property without due process of law. The first of them limits the power of the federal government, while the second one, passed some years later, limits the power of the states. The Due Process Clause has two aspects: procedural and substantive. The Procedural Due Process guarantees a fair procedure before carrying out decisions depriving life, liberty or property. The term «substantive cases» began to take form in 1930s case law as a distinction of procedural cases. The concept has greatly evolved since, going through different stages. Nowadays the Substantive Due Process (SDP) involves cases where due process appears in relation to freedom, and some outcomes are sought, rather than simply questioning the procedures and their effects. To summarize, it can be stated that when a law or policy is said to affect the Due Process Clause, if its substantive aspect is involved, it means the same as when it is said to affect the Fourteenth Amendment's liberty interest. See L. H. SeE Tribe, American Constitutional Law, Mineola, The Foundation Press, 1988, pp. 769 et seq., and J. E. NowAK and R. D. Rotunda, Constitutional Law, Saint Paul, West Group, 1991, pp. 351-562.

31 The Court points out the earliest reference to suicide in common law, which traces back to the 13th century, made by one of the first English jurists, Henry of Bracton. The Court uses the work of G. WoodBine, Bracton on Laws and Customs of England, Cambridge (Massachusetts), Harvard University Press, 1968, p. 423; quoted in Washington et al. v. Glucksberg et al., 521 U.S. 702, 711 (1997).
} 
be rooted in the Nation's history and tradition. Secondly, a careful description of the liberty to be included in the area of protection of the Due Process must be provided.

Being rejected that the asserted liberty had a place in the Nation's history and traditions, respondents pointed to two formers Supreme Court cases, Cruzan and Casey ${ }^{32}$, holding that the Court concluded in both that protections of the Due Process Clause include a right to commit suicide with another's assistance. With this «careful description» of respondents' claim in mind, the Supreme Court rejected such conclusion.

On the one hand, suicide may be part of a person's liberty, whatever it might be called («agere licere» or personal autonomy at the constitutional Spanish jurisprudence), but never - like the «right to refuse» acknowledged in Cruzan - of the common law, the statutes, the historical tradition or the case-law. This same interpretation can be found in the jurisprudence of several constitutional courts or institutions vested with the power to defend the human rights. For example, the first of the «GRAPO judgments» in the Spanish jurisprudence ${ }^{33}$, the case of D. Pretty $v$. Director of Public Prosecutions ${ }^{34}$ in the United Kingdom and Rodriguez v. British Columbia ${ }^{35}$ in the Canadian jurisprudence. We could also highlight the European Court of Human Rights' judgment in case Haas v. Switzerland ${ }^{36}$ and the decision by the Human Rights Committee in the case of Sanlés $v$. Spain $^{37}$. All of them held that there is no a right to die as a potential negative dimension of the right to life $\mathrm{e}^{38}$.

On the other hand, the alleged consistency with the Casey case cannot either be admitted: the fact that many rights protected by the Due Process Clause derive from the personal autonomy does not imply that all personal decisions have this protection. Besides, the respondents offer an ambiguous and generic description of the alleged right, which does not fulfill the

32 Planned Parenthood of Southeastern PA. v. Casey, 505 U.S. 833 (1992).

${ }^{33}$ Constitutional Court Judgment number 120/1990, June the $27^{\text {th }}$.

${ }^{34}$ Case of D. Pretty v. Director of Public Prosecutions and Secretary of State for the Home Department, November the 29 $9^{\text {th }}, 2001$ [(2001) UKHL 61].

35 Case of Rodriguez v. British Columbia (Attorney General), March the $25^{\text {th }}, 1993$ [(1993) 3 S.C.R.].

${ }^{36}$ Case of Haas v. Switzerland, ECHR, January the 20 ${ }^{\text {th }}, 2011(31322 / 07)$.

${ }^{37}$ Case of M. Sanlés Sanlés v. Spain, March the $30^{\text {th }}, 2004$ (communication number 1024/2001).

38 On this subject, see L. M. DíEz-PicAzo Giménez, Sistema de derechos fundamentales, Cizur Menor, Thomson-Civitas, 2008, pp. 229-231, and J. Pérez Royo, Curso de Derecho Constitucional, Madrid, Marcial Pons, 2010, pp. 254 et seq. 
requisite of a necessary careful description so that it can be included in the Due Process Clause ${ }^{39}$.

As expected, the Supreme Court ruled that the right to the physician-assisted suicide is not a liberty interest protected by the Due Process Clause. Finally the Court held as well that by forbidding the assisted suicide the act pursues the protection of several legitimate public interests, which essentially concur with those intended to be protected in the rightto-die cases: preservation of life, prevention of suicide, integrity of ethics in Medicine and protection of the most vulnerable groups ${ }^{40}$.

\section{CURRENT STATE REGULATIONS ON PHYSICIAN- ASSISTED SUICIDE IN THE UNITED STATES}

As stated above, the United States Supreme Court concluded that the state acts punishing the physician-assisted suicide are not contrary to the Constitution. However, it doesn't prevent the state statutes from acknowledging assisted suicide as a legal right instead, something very exceptional to date.

Oregon was the first state to legalize this practice. In 1994 Oregon voters approved the Ballot Measure 16, a citizen initiative — sponsored by the Hemlock Society, which later became Compassion and Choices-, which legitimated the Death with Dignity Act ${ }^{41}$. This act allowed competent adults with a life expectancy of 6 months or less to ask their physician for a prescription of life-ending medication. But a few days after the Oregon Death with Dignity Act came into effect, a group of citizens challenged

39 Abstract concepts like «control of the last days» do not accomplish that accuracy requirement.

${ }^{40}$ The last public interest legitimizing the patients' rights in the context of the right-todie cases was the protection of innocent third parties, which allowed the coercive imposition of treatment, for instance in order to protect the dependent child or the nasciturus (in the case of pregnant women). In the cases of physician-assisted suicide, the vulnerable group consists of terminally ill patients, although it extends also to the elderly and the disabled, whom they want to protect from «prejudice, negative and inaccurate stereotypes and societal indifference» [Washington v. Glucksberg et al., 521 U.S. 702, 732 (1997)]. The Supreme Court points a fifth interest usually applied in these cases: the slippery slope, that could lead from this practice to euthanasia. From my point of view, this interest could be included in the second interest- the prevention of suicide- understood in a broad sense.

${ }^{41}$ The Oregon Constitution allows voters to propose, approve or reject laws and constitutional amendments, independently from the Legislative Assembly. Furthermore, it gives the voters the power to pass or reject any action originated in the Assembly. 
its constitutionality in the U.S. District Court, which ruled in their favor by considering that the act violated the Equal Protection Clause ${ }^{42}$. Three years later, after the decision was overruled by the Ninth Circuit Court of Appeals for procedural reasons, the Oregon Legislative Assembly sent the act back to the citizens and «Measure 51» was adopted by a wider margin than the first time. Although the legal battle over the act has been going on in courts for many years, it has been steadily applied ever since.

Washington was the second state to regulate assisted suicide. A similar process to the one is Oregon was followed, being its act taken as a reference. The Initiative 119 tried to introduce an amendment to the Washington's Natural Death Act of 1979 so that physician-assisted suicide was legalized. It was rejected by the voters in 1991. It was not until 2008 that Washington voters approved the Initiative 1000, based on Oregon Measure $16^{43}$. This initiative established the Washington Death with Dignity Act, which legalized physician-assisted dying for adults with a life expectancy of 6 months or less. Like the Oregon act, Washington's law requires the patient to self-administer the medication without the physician assistance.

In Montana, the third state to authorize this practice, it was its Supreme Court who legitimized it when hearing a case from a patient who wanted to be assisted in dying. It was the Baxter $v$. Montan $a^{44}$ case, where a terminally-ill patient requested his constitutional right to assisted suicide to be acknowledged. He also demanded that the practice didn't have any legal consequence for the physicians assisting him, who were also plaintiffs. The District Court held that the Montana constitutional rights of human dignity and privacy, taken together, encompass the right to die with dignity and to be assisted by a physician to do so. An appeal was filed and heard by the Montana Supreme Court, which decided not to rule upon the constitutional ground. The Court only had to point out that there was no indication in the state legislation from which it could be concluded that physician aid in dying to adult patients was against the public policy. Therefore, the physician would not be criminally responsible if the patient consented to it.

In May 2013 Vermont approved the Patient Choice and Control at End of Life Act, becoming the first state to enact such a law just by the legislature (the name of the legislative body in this state is General Assembly), as

\footnotetext{
${ }^{42}$ Lee v. State of Oregon, 891 F.Supp. 1439 (D.Or.1995).

43 Firstly fifty-four per cent of the popular vote rejected Initiative 119, but then Initiative 120 was adopted by the support of almost fifty-eight per cent of the votes.

44354 Mont. 234, 224 P.3d 1211 (2009).
} 
it was never put to a referendum ${ }^{45}$. The act includes very similar provisions to the Oregon and Washington acts: it allows terminally-ill adult patients -18 years old or older - residents of Vermont, competent to make an informed decision and whose life expectancy is 6 months or less, to be prescribed aid-in-dying medication.

One of the differences between those acts and the one from Vermont lies in the information that the physician must provide to the patient. In the first two acts, although it is generally provided that the physician gives the patient all kinds of information, the laws don't compel doctors to inform the patient specifically about the possibility of being prescribed lethal drugs. On the contrary, the Patient Choice and Control at End of Life Act, after establishing the voluntary nature of the physicians involvement in the lethal practice, it states that they are forced to inform the patient about all the options available to face the illness, including the possibility of being prescribed drugs to end life. Physicians not willing to provide that information must refer the patient to another doctor or take all necessary measures so the patient receives all the information about this alternative procedure.

California has very recently become the second state to enact a law like the one in Vermont. The End Of Life Option Act was passed in a legislative «extraordinary session» in march 2016, and went into effect in june 9. After a first try to legalize this practice unsuccessfully, the End of Life Option Act was passed without being put to a referendum, as was the case of the Vermont act. The law requires two doctors to agree that a patient has six months or less to live and it is also necessary that the patient is at least 18 years old with the capacity to make medical decisions. Patients have to be able as well to swallow the medication themselves and they must affirm in writing, 48 hours before taking the medication, that they will do so.

Finally, the assisted suicide was recently legalized in New Mexico judicially, as it happened in Nebraska through the Supreme Court's ruling examined before, but in this case by a federal court. On January 13, 2014 the judges of the Second Judicial District, based on the case of a cancer patient who wished to be prescribed the lethal medication without the physicians suffering any legal consequences, ruled that the Court could not envision:

${ }^{45}$ The End of Life Choice Bill was approved by the House of Representatives by a 75-65 vote. 
«A right more fundamental, more private or more integral to the liberty, safety and happiness of a New Mexican than the right of a competent, terminally ill patient to choose aid in dying» ${ }^{46}$.

There are states where the legalization of this practice has been proposed without succeeding so far. It is the case of New Jersey or Massachusetts where the majority of citizens voted against the proposal. The constitutional basis of physician-assisted suicide has been rejected also in the judicial area. The Florida Supreme Court, in a totally opposite way to what was recently stated in New Mexico, denied that the state Constitution's privacy amendment guaranteed terminally-ill patients the right to be assisted in dying and even held that the preservation of life is a compelling state interest which can only be guaranteed by defending the law which prohibits the assisted suicide ${ }^{47}$. The Alaska Supreme Court reached a similar conclusion, as it denied that the state Constitution's privacy and liberty entailed the right of terminally-ill patients to be assisted in dying by a physician. Although this Supreme Court also declared that the state act prohibiting such a practice did not violate the constitutional right to equal protection, as alleged by the plaintiffs, it didn't go so far as to consider that this was the only option for the law to be constitutional, as was the case in Florida. This decision is therefore more in line with the United States Supreme Court's doctrine as it did consider that the physician-assisted suicide might be permitted by the state Constitution if the lawmaker decided to legalize it ${ }^{48}$.

\section{CONCLUDING REMARKS}

To summarize, according to the Supreme Court's jurisprudence, physician-assisted suicide is not protected by the Due Process Clause or the Fourteenth Amendment's liberty interest, as it does not entail a right to end one's own life. The Supreme Court denied the existence of the constitutional right to die and therefore of a right to aid in doing so by a third person on its decisions in Vacco and Glucksberg, both originated in the

46 The Court then wondered: «If decisions made in the shadow of one's imminent death regarding how they and their loved ones will face that death are not fundamental and at the core of these constitutional guarantees, then what decisions are?» [Morris v. New Mexico, No. D-202-CV 2012-02909, paragraph HH].

47 Krischer v. Mciver, No. 89837, 1997.

48 Sampson v. Alaska, 31 P.3d 88 (Alaska, 2001). 
challenge of the state act punishing aid-in-dying. Moreover, this doctrine is in line with the jurisprudence of most of the constitutional or quasi-constitutional courts.

The fact that the state laws penalizing the aid-in-dying haven't been considered unconstitutional has not prevented other states from passing laws recognizing conversely this practice as a legal right. Other states have judicially determined that, although the prohibition was not against the U.S. Constitution, physician-assisted suicide was indeed an expression of the state constitutional rights.

Anyhow, the states that have legitimized this practice are only a few, as the issue still gives rise to a great controversy, not only in the U.S. society but almost everywhere where it has been raised. In this regard, the diversity of the debate is shown by the significant different ways in which the states have faced it, from those recognizing the aid-in-dying legally as a right to those protecting themselves against this practice forbidding it expressely by law in the medical field ${ }^{49}$.

As a means of a conclusion, two ideas can be put forward. Leaving to one side the different opinions raised by this kind of procedures, it has to be admitted that its legalization would mean and objective improvement in the juridical situation both of the patient and the physician. Besides, there is certainly another positive aspect deriving from the regulation of physician-assisted suicide. The implication of the physician being less direct than in active euthanasia, from an ethical point of view physician-assisted suicide could entail a lesser compromise of the professional in the act of ending the patient's life.

${ }^{49}$ Such is the case with the State of Alabama. Other states have no provisions regarding aid-in-dying. Therefore, it is unclear whether in these states providing this type of physician care is illegal.

This information comes essentially from the following web sites bttp://www. patientsrightscouncil.org/site/assisted-suicide-state-laws/and http://euthanasia.procon.org/ view.resource.php? resourceID $=000132$ (last consulted on December, 29th 2015). 
